\title{
A comparison of diagnostic algorithms and clinical parameters to diagnose ventilator-associated pneumonia: A prospective observational study
}

Farshid Rahimibashar

Hamadan University of Medical Sciences

Andrew Carl Miller

Nazareth Hospital https://orcid.org/0000-0001-8474-5090

Mojtaba H. Yaghoobi

Alborz University of Medical Sciences

Amir Vahedian-Azimi ( $\nabla$ amirvahedian63@gmail.com )

Baqiyatallah University of Medical Sciences https://orcid.org/0000-0002-1678-7608

\section{Research article}

Keywords: Ventilator-associated pneumonia, Cross infection, Artificial Respiration, Critical care

Posted Date: January 12th, 2021

DOI: https://doi.org/10.21203/rs.3.rs-31703/v2

License: @ (i) This work is licensed under a Creative Commons Attribution 4.0 International License. Read Full License

Version of Record: A version of this preprint was published at BMC Pulmonary Medicine on May 13th, 2021. See the published version at https://doi.org/10.1186/s12890-021-01527-1. 


\section{Abstract}

BACKGROUND: Suspicion and clinical criteria continue to serve as the foundation for ventilator-associated pneumonia (VAP) diagnosis, however the criteria used to diagnose VAP vary widely. Data from head-to-head comparisons of clinical diagnostic algorithms is lacking, thus a prospective observational study was performed to determine the performance characteristics of the Johanson criteria, Clinical Pulmonary Infection Score (CPIS), and Centers for Disease Control and Prevention's National Healthcare Safety Network (CDC/NHSN) criteria as compared to Hospital in Europe Link for Infection Control through Surveillance (HELICS) reference standard.

METHODS: A prospective observational cohort study was performed in three mixed medical-surgical ICUs from one academic medical center from 1 October 2016 to 30 April 2018. VAP diagnostic criteria were applied to each patient including CDC/NHSN, CPIS, HELICS and Johanson criteria. Tracheal aspirate cultures (TAC) and serum procalcitonin values were obtained for each patient.

RESULTS: Eighty-five patients were enrolled (VAP 44, controls 41). Using HELICS as the reference standard, the respective true positive rate (TPR; sensitivity), true negative rate (TNR; specificity), false positive rate (FPR; fall-out) and false negative rate (FNR; miss-rate) for each of the assessed diagnostic algorithms were: CDC/NHSN (Sensitivity 54.2\%; Specificity 100\%; FPR 95\%; FNR 0\%), CPIS (Sensitivity $68.75 \%$; Specificity $95.23 \%$; FPR $50 \%$, FNR $2 \%$ ), Johanson (Sensitivity $67.69 \%$; Specificity $95 \%$; FPR $52.5 \%$, FNR $2 \%$ ). The positive TAC rate was $81.2 \%$. The sensitivity for positive TAC with the serum procalcitonin level $>0.5 \mathrm{ng} / \mathrm{ml}$ was $51.8 \%$.

CONCLUSION: VAP remains a considerable source of morbidity and mortality in modern ICUs. The optimal diagnostic method remains unclear. Using HELICS criteria as the reference standard, CPIS had the greatest comparative diagnostic accuracy, whereas the sensitivity of the CDC/NHSN was only marginally better than a positive TAC plus serum procalcitonin $>0.5 \mathrm{ng} / \mathrm{ml}$. Algorithm accuracy was improved by adding serum procalcitonin $>0.5 \mathrm{ng} / \mathrm{ml}$, but not positive quantitative TAC.

\section{Background}

The incidence of nosocomial infections (NI) amongst intensive care unit (ICU) patients is 2-5 times that of general admissions [1]. Amongst the most prevalent and threatening ICU NIs is ventilator-associated pneumonia (VAP), which may develop in patients receiving invasive mechanically ventilated (MV) for $\geq 48$ hours [2-6]. VAP has a cumulative incidence of 10-45\%, and an attributable risk of 5-27\% [7-12]. VAP-associated comorbidities include prolonged duration of MV, delayed MV weaning, increased antibiotic consumption, prolonged ICU and hospital length-of-stay (LOS), increased treatment-related expenditures, and increased crude and attributed mortality [2-6,13-15].

Between one-third and one-half of all VAP-related deaths are directly attributable to the infection, with Pseudomonas aeruginosa and Acinetobacter spp. exacting higher tolls [16-19]. Recent studies have reappraised the impact of VAP on mortality to be 10\% [20,21], with surgical patients and those with mid-range illness severity presenting the highest associated risk [22], and trauma status being associated with a lower mortality than nontrauma status [23]. Accordingly, VAP prevention has emerged as a high priority [24,25]. Since 2004, the Institute for Healthcare Improvement has recommended that all ICUs implement a ventilator bundle to reduce the VAP rate as part of its' 5 Million Lives campaign [24,25]. In line with this effort, one bundle component is the accurate diagnosis and determination of VAP incidence [24-26]. However, the best diagnostic strategy in patients with suspected VAP remains contentious, and research in this field is limited by the lack of a consensus 'gold standard' definition against which to test the diagnostic accuracy of new diagnostic algorithms or methods of detection. The central problem lies in striking a balance between avoiding delayed initiation of necessary antibiotics and reducing the inappropriate use of broad-spectrum antibiotics. Failure to achieve the first goal leads to excess mortality, while failure to achieve the second is a major factor in the seemingly inexorable increase in multi-antibiotic-resistant pathogens with their attendant morbidity, mortality, and economic costs [27]. In fact, VAP may statistically "disappear" totally if criteria are overly stringent [28].

VAP diagnosis remains challenging as clinical signs and symptoms may be non-specific. Whereas the clinical approach to diagnosis has been criticized for being overly sensitive (leading to increased antibiotic use), the major limitation of the histopathological 'gold standard' (ante- or postmortem within 96 hours of death) is its limited availability and reliability. Indeed, not every suspected VAP could (or should) be biopsied. Postmortem lung histology may reveal false negative results if biopsy specimens miss the area of active disease, or false positive results if clinically insignificant bronchiolitis or resolving pneumonia complicates the patient's illness. Moreover, the diagnostic criteria based on pathologic examination of lung tissue are not well defined, have varied over time, and have lacked standardized criteria for processing and interpreting laboratory specimens [29-31].

Similarly, quantitative respiratory cultures may also produce false negative results depending on the location sampled, or antibiotic administration prior to sampling. Likewise, false positives may occur when there is lung colonization in the presence of alternative lung pathologies. Unfortunately, investigators have identified fairly poor correlation between these two methods (microbiologic vs. histopathologic) challenging the value of histological examination of lung tissue in diagnosing VAP [30,32].

As none of the available diagnostic tests, performed alone, can provide an accurate diagnosis of VAP, a diagnostic strategy incorporating several criteria has been viewed by many to be a good compromise. To this end, great effort has been expended to generate standardized diagnostic 
algorithms that incorporate clinical, radiographic and microbiological data. Some examples (Table 1) include: Centers for Disease Control and Prevention's National Healthcare Safety Network (CDC/NHSN) [33], Clinical Pulmonary Infection Score (CPIS) [34], Hospital in Europe Link for Infection Control through Surveillance (HELICS) [35], Johanson criteria [36], and others [37,38]. As compared to immediate post-mortem lung biopsies, clinical criteria have reasonable diagnostic performance but may be highly impacted by the diagnostic thresholds used. For a CPIS threshold $\geq 6$, one meta-analysis reported a pooled sensitivity $73.8 \%$ (95\% Cl 50.6-88.5, low certainty) and specificity of $66.4 \%$ (95\% $\mathrm{Cl} 43.9-83.3$, low certainty) [39-42]. However, using a CPIS threshold $\geq 7$, the sensitivity and specificity has been reported to be $85 \%$ and $91 \%$ respectively [43]. Conversely, the sensitivity and specificity of the Johanson criteria is only $64-69 \%$ and $75 \%$ respectively [42,44], and that of the CDC/NHSN and HELICS criteria remains unclear.

These findings should be viewed with caution, however, because many of these studies were not powered for these endpoints. Additionally, the timing of culture specimen collection (e.g. ante- versus post-mortem) may also impact results [45]. Moreover, the standard diagnosis comparator across the literature to which algorithms are compared as well as and inter-algorithm agreement varies significantly (Table 2), making inter-study comparisons difficult [46]. Even with strict criteria, the interpretation of some factors, such as the radiographs or tracheal secretions, can be very subjective. Additionally, VAP identification via diagnostic scoring tools may underperform in burn [47] and surgical sub-populations [48], and has been shown to correlate poorly with International Classification of Diseases (ICD) coding data, thereby limiting large-scale epidemiologic study $[49,50]$.

Additionally, an elevated serum procalcitonin level is an independent prognostic biomarker of mortality risk in critically ill VAP patients [51]. Whereas some have advocated for its inclusion in diagnostic algorithms [52], guidelines have recommended against incorporating it into diagnostic algorithms aimed at determining when to initate antimicrobial treatment [53]. Rather, it's current utility lies in helping clinicians determine when to deescalate or stop antibiotics [53-56].

A highly performing VAP diagnostic method is greatly needed. International guidelines disagree on the use of clinical algorithms for risk stratification to determine treatment [22,53]. Data comparing algorithm performance head-to-head is lacking, and as most such data stems from high-income countries, and great need exists to both compare the algorithms head-to-head and supplement the international data pool with information from lowto-middle income countries (LMIC). To this end, a prospective non-randomized study was conducted to determine if in patients with VAP, does application of the CDC/NHSN [33], CPIS [34], or Johanson criteria [36] criteria provide the greatest diagnostic performance characteristics as compared to HELICS [35] as the reference standard. HELICS was used as the reference standard as it is the definition currently used in much of Europe, Australia, and the near- and middle east (including Iran).

\section{Materials And Methods}

A prospective observational cohort study was performed in three mixed medical-surgical ICUs from one academic medical center from 1 October 2016 to 30 April 2018. The study was approved by the Investigational Review Board at Hamadan University of Medical Sciences, Hamadan, Iran (IR.UMSAHA.REC.1395.23). All study parts were reviewed according to the Strengthening the Reporting of Observational Studies in Epidemiology 'STROBE' guideline [57]. Consent was required and covered both study participation and publication of de-identified aggregate findings. Surrogate consent from the patient's legal guardian or designated health proxy was permitted in cases where the subject lacked decision-making capacity. All patients that survived and regained their faculties were informed of the project. All data generated or analyzed during this study are included in this article. De-identified individual subject data may be available from the corresponding author on reasonable.

Patients were eligible for study participation if: (1) age $\geq 18$ years, (2) admitted to the ICU $>48$ hours, ( 3 ) receiving invasive MV $>48$ hours (any mode except high frequency percussive ventilation or high frequency oscillatory ventilation), (4) full-code status, and (5) informed consent obtained from the patient, legal guardian or healthcare surrogate upon ICU admission (prior to intubation). Patients with any limitation of code status including (but not limited to) No Code, Do Not Resuscitate, or Do Not Intubate were excluded (Figure 1). Patients with known pregnancy were excluded.

Patient selection was performed by an enrollment team of two physicians ( 1 critical care, 1 infectious disease) not directly involved in the study. All consecutive patients identified at the participating ICUs with VAP according to the HELICS criteria were eligible. Each case patient was matched by the enrollment team, which was blinded to the outcome, with another ICU patient that did not have VAP. Matching was based on: (1) admission indication; (2) ICU LOS $\geq 48$ hours; (3) receiving invasive MV $>48$ hours (any mode except high frequency percussive ventilation or high frequency oscillatory ventilation as these preclude proper calculation of the $\mathrm{CBC} / \mathrm{NHSN}$ criteria); (4) severity of illness at ICU admission as quantified by the Acute Physiology and Chronic Health Evaluation (APACHE) II score >15, (5) full code status, and (6) age $\geq 18$ years.

VAP diagnosis was made independently by the treating clinical team. Diagnostic criteria were according to HELICS criteria [35] in accordance with in institutional standard and other published studies [2,58-61] as it is the definition currently used in much of Europe, Australia, and the near- and middle east (including Iran). Chest radiograph interpretation was undertaken "off-line" and by a team of 3 physicians (1 radiology, 1 critical care, 1 pulmonology) who were independent of the treating team. Kendal agreement coefficient between the clinicians in chest radiograph interpretation was 0.99 . Procalcitonin was measured at the time of initial VAP suspicion. A single value was used, and thresholds were in accordance with prior published studies [62]. 
Protected tracheal aspirate (TA) samples were obtained through a sterile 12 French catheter (SUPA Medical Devices, Tehran, Iran). This catheter is placed in the trachea by advancing through the endotracheal tube until resistance was encountered (level of the carina) and retracted approximately $2 \mathrm{~cm}$. To obtain TA samples, 5-10 mL of sterile saline was instilled followed by aspiration into a sterile syringe. This generally yielded an aspirate of $2-3 \mathrm{cc}$. The samples were then transferred to the microbiology laboratory for processing and examination within 30 minutes. The materials were evaluated by gram-staining and quantitative cultures. Light microscopy was utilized to assess gram stains for bacteria and white blood cells. The samples were vortexed for one minute at 3,000 rpm, diluted with saline to 1:10 ratio, and 0.01cc inoculated onto blood agar, chocolate agar, and MacConkey agar plates. Cultures were incubated at $35 \pm 1^{\circ} \mathrm{C}$ for 24 , followed by quantitative bacterial evaluation. The cut-off values for bacterial colony counts were taken as $\geq 105$ colony forming units (CFU)/cc. When more than one bacteria type was identified, a separate colony count was performed for each. Microbial identification and antimicrobial susceptibility testing were performed using the automated Vitek 2 Advanced Expert System (bioMérieux, Marcy-l'Étoile, France).

The criteria for sample rejection were improperly labeled specimens, specimens with transport times exceeding study standards, clotted specimens; specimens not submitted in an appropriate transport container, insufficient volume or external contamination. If an unacceptable specimen was received, the physician or patient's nurse was notified, and another specimen was requested before the specimen was discarded.

\section{Data Collection}

Screening, data collection and reporting was undertaken by a trained, dedicated full-time nurse. The data collection tool was a two-part checklist including demographic variables, clinical and microbiological variables. The tool was developed during two 90 -minute meetings by a consensus multidisciplinary panel consisting of 17 physicians representing critical care $(n=5)$, anesthesia $(n=3)$, pulmonology ( $n=5)$, internal medicine $(n=3)$, and forensic medicine $(n=1)$, and 10 critical care nurses. The Quantitative face validity was determined using Impact Score (2.5-4.5), and quantitative content validity was determined via 27 panelists. The measured content validity ratio and content validity index were 0.51 and 0.89 respectively. The internal validity of the questionnaire was determined by the Cronbach's alpha coefficient to be 0.91 .

\section{Statistics}

Statistical analyses were performed using IBM® SPSS version 22.0 (IBM Corp, Armonk, USA). Data were summarized using mean \pm standard deviation (SD) for quantitative variables and frequency (\%) for qualitative variables. Study size was determined by a prior sample size calculation. Considering a VAP prevalence of $0.5,95 \%$ confidence interval level, $80 \%$ power, and absolute error $10 \%$, the necessary sample size was calculated to be 85 patients.

Normally distributed variables were compared using the Student's t-test. Categorical variables were compared using Chi-square $\left(\chi^{2}\right)$ test or Fisher's exact test when appropriate. Trend of change in distribution of relative frequencies between ordinal data were compared using $\chi^{2}$ test for trend. The Youden index (or Youden's J Statistic) was calculated as: $J$ = sensitivity + specificity -1 .

\section{Results}

One-hundred twenty-nine patients were screened, and 85 were included in the final analysis (Figure 1). The mean age was $46.94 \pm 18.90$ years with a male predominance (72.9\%). Measures of illness severity and hospital course metrics are listed in Table 3. Positive tracheal culture was seen in 81.2\% with cultures yielding Acinetobacter (37.6\%), Staphylococcus aureus (22.4\%), Escherichia coli (14.1\%), Pseudomonas (10.6\%), Klebsiella (10.6\%), and Proteus (3.5\%). Multiple drug resistant (MDR) organisms were identified in $36.5 \%$ of isolates. Using HELICS as the reference standard, the true positive rate (TPR; sensitivity) and true negative rates (TNR; specificity) are presented in Table 4. The false positive rate (FPR, fall-out) and false negative rates (FNR; miss-rate) for each of the assessed diagnostic algorithms were: CDC/NHSN (FPR 95\%, FNR 0\%), CPIS (FPR 50\%, FNR 2\%), Johnson (FPR 52.5\%, FNR 2\%). Additionally, when compared to the HELICS standard, the sensitivity for positive tracheal culture with the serum procalcitonin level $>0.5 \mathrm{ng} / \mathrm{ml}$ was $51.8 \%$, lower than each of the algorithms assessed. The highest Youden index, a measure of diagnostic accuracy compared to the reference standard, was seen with CPIS (Table 4).

The Kappa agreement coefficient results between each diagnostic algorithm and either serum procalcitonin level or positive tracheal culture is highlighted in Table 5. The greatest correlation between positive VAP assessment and serum procalcitonin levels $\geq 0.5 \mathrm{ng} / \mathrm{ml}$ was observed with the Johanson method and CPIS (both roughly 70\%).

As stated previously, CPIS correlated most closely with the HELICS standard. However, when comparing the three tested algorithms (excluding HELICS), CPIS displayed near perfect agreement with the much simpler and historical Johanson criteria, whereas CDC/NHSN showed only slight 
agreement with either of the other algorithms (Table 6). Moreover, CPIS correlated most closely with traditional clinical markers for pneumonia (Table 7).

\section{Discussion}

Suspicion and clinical criteria continue to serve as the foundation for VAP diagnosis, however the criteria used to diagnose VAP vary widely, impacting reports of incidence and outcomes. As previously discussed, the use of histopathology and microbiology alone carries considerable limitations. Numerous diagnostic algorithms have been proposed to standardize the diagnosis, allow for easier identification, and improve interstudy comparability. Unfortunately, inter-algorithm agreement varies significantly (Table 2), making comparisons between studies difficult. Even with strict criteria, the interpretation of some factors (e.g. radiographs) may be subjective. Additionally, diagnostic algorithm performance varies by patient population $[47,48]$ and correlates poorly with coding data[49,50] and postmortem histology $[40]$. Even so, a need exists for an effective tool that may be utilized in the clinical environment to aid real time VAP diagnosis.

VAP diagnosis is usually based on 2 or 3 components: (1) systemic signs of infection, (2) new or worsening infiltrates seen on chest imaging, and (3) microbiologic evidence of pulmonary parenchymal infection when available [40]. However, the FPR is high for chest roentenograms [63,64], much as it is for clinical symptoms such as fever (42\%) or purulent airway secretions (67\%) [63]. Moreover, combining these criteria does little to improve diagnostic performance [42].

Patient characteristics in our cohort were largely similar to those of other published cohorts, including age [9,21,65-69], male gender predominance [9,66,70-74], and APACHE II score [66-69,72,73,75], MV duration [70,73,75-77], re-intubation rates [9,73,78], ICU LOS [68$71,73,74,76]$, and hospital LOS $[68,71,73,76]$. In particular, the ICU LOS and mortality were similar to other published VAP cohorts in Iran $[74,79,80]$. Moreover, the array of cultured and MDR pathogens, was consistent with prior studies [72].

A direct comparison of the correlation and diagnostic performance of the VAP algorithms is important for both individual patient care and epidemiology, cross-study comparisons, and meta-analyses. If algorithms have suboptimal sensitivity, specificity, or do not correlate well, subsequent meta-analyses and epidemiologic investigations will be flawed from inception by selection bias (in part). Direct comparisons of the performance characteristics of the CDC/NHSN, CPIS, HELICS, and the historical Johanson criteria have not previously been reported. Moreover, only two studies were identified that compared VAP diagnostic algorithms $[46,81]$. HELICS was chosen as the reference standard due as it is widely used internationally (Europe, Australia, Near- and Middle East [including Iran]), and has been used as the reference standard for numerous other studies [2,19,58-61]. CDC/NHSN and CPIS criteria were chosen as the other two most widely recognized and used criteria (especially in North America). The Johanson criteria was selected as the third comparator for its historical significance. The sensitivity of the CPIS and Johanson methods was moderate, whereas CDC/NHSN was poor. FPR's were high for all (CDC/NHSN, CPIS, Johanson), but greatest for CDC/NHSN (Table 4). Moreover, the diagnostic agreement was substantial for CPIS, moderate for Johanson, and only slight for CDC/NHSN (Table 5). Algorithm accuracy was improved by adding serum procalcitonin $>0.5 \mathrm{ng} / \mathrm{ml}$, however, similar to prior reports, the addition of microbiological data to the clinical definitions did not significantly improve the sensitivity or specificity [40].

These findings suggest that combining cohorts based on HELICS and CPIS may be reasonable for meta-analysis or population studies, but the same may not be true for studies based on CDC/NHSN criteria as the diagnostic agreement is poor. Moreover, it is recommended that studies report serum procalcitonin values to better refine their data sets to optimize data utility as diagnostic algorithms evolve to best facilitate future meta-analyses and as procalcitonin may correlate with mortality [82]. Lastly, this data highlights how little progress these complicated VAP diagnostic algorithms have made beyond that of the historical and simple Johanson criteria. These algorithms will most certainly undergo modification, and it is important that investigators clearly define their patient populations and present the data in a way that allows the data to inform future decisions as the diagnostic techniques evolve.

\section{Limitations}

The non-randomized methodology and absence of histopathology confirmation of VAP diagnosis are limitations of this study. This study was performed in a resource-limited setting in a low-to-middle income country (LMIC) and limiting the study cohort to those with ante- or post-mortem histology would have introduced selection bias and served as a barrier for subject recruitment.

The use of TAC specimens is a minor limitation as positive quantitative TAC's have been reported to have a high degree of correlation with bronchoalveolar lavage in VAP patients and are a useful minimally invasive diagnostic tool $[41,83,84]$.

\section{Conclusion}

Ventilator-associated pneumonia remains a considerable source of morbidity and mortality in modern ICUs. The optimal diagnostic method remains unclear. Using HELICS criteria as the reference standard, CPIS displayed substantial diagnostic agreement whereas CDC/NHSN and Johanson criteria displayed slight and moderate agreement respectively. Accuracy was improved with the addition of serum procalcitonin $>0.5 \mathrm{ng} / \mathrm{ml}$, but not 
positive quantitative endotracheal aspirate culture. These findings suggest that combining cohorts based on HELICS and CPIS may be reasonable for meta-analysis or population studies, but the same may not be true for studies based on CDC/NHSN criteria.

\section{Abbreviations}

$\begin{array}{ll}\text { VAP } & \text { Ventilator-associated pneumonia } \\ \text { CPIS } & \text { Clinical Pulmonary Infection Score } \\ \text { CDC/NHSN } & \text { Centers for Disease Control and Prevention's Nation } \\ \text { through Surveillance } \\ \text { TP } & \text { True positive } \\ \text { FN } & \text { False negative } \\ \text { NI } & \text { Nosocomial infection } \\ \text { ICU } & \text { Intensive care unit } \\ \text { MV } & \text { Mechanical ventilation } \\ \text { LOS } & \text { Length-of-stay } \\ \text { APACHE } & \text { Acute Physiology and Chronic Health Evaluation } \\ \text { SD } & \text { Standard deviation } \\ \chi^{2} & \text { Chi-square test } \\ J & \text { Youden's J Statistic, or Youden Index } \\ \text { MDR } & \text { Multiple drug resistant }\end{array}$

\section{Declarations}

Ethics approval and consent to participate: The study was approved by the Investigational Review Board at Hamadan University of Medical Sciences, Hamadan, Iran (IR.UMSAHA.REC.1395.23)._Consent was required and covered both study participation and publication of de-identified aggregate findings. Surrogate consent from the patient's legal guardian or designated health proxy was permitted in cases where the subject lacked decision-making capacity. All patients that survived and regained their faculties were informed of the project.

Availability of data and material: All data generated or analyzed during this study are included in this article. De-identified individual subject data may be available from the corresponding author on reasonable.

Competing interests: The authors have no competing or conflicts of interest to disclose.

Funding: No funding was received for this research.

Author's Contributions: The original idea was conceived by FRB and AVA. Study design, implementation, and data acquisition was performed by FRB, MHY and AVA. Data analysis was performed by AVA and ACM. Manuscript writing and revision was performed by ACM and AVA. All authors read and approved the final manuscript.

Acknowledgements: None

\section{References}

1. Li Y, Cao X, Ge H, Jiang Y, Zhou H, Zheng W. Targeted surveillance of nosocomial infection in intensive care units of 176 hospitals in Jiangsu province, China. J Hosp Infect. 2018;99(1):36-41. doi: 10.1016/j.jhin.2017.10.009

2. Álvarez Lerma F, Sánchez García M, Lorente L, Gordo F, Añón JM, Álvarez J, et al. Guidelines for the prevention of ventilator-associated pneumonia and their implementation. The Spanish "Zero-VAP" bundle. Med Intensiva. 2014 May;38(4):226-36. doi:

10.1016/j.medin.2013.12.007

3. Righi E, Aggazzotti G, Ferrari E, Giovanardi C, Busani S, Rinaldi L, et al. Trends in ventilator-associated pneumonia: impact of a ventilator care bundle in an Italian tertiary care hospital intensive care unit. Am J Infect Control. 2014;42(12):1312-6. doi: 10.1016/j.ajic.2014.08.009 
4. Tedja R, Nowacki A, Fraser T, Fatica C, Griffiths L, Gordon S, et al. The impact of multidrug resistance on outcomes in ventilator-associated pneumonia. Am J Infect Control. 2014;42(5):542-5. doi: 10.1016/j.ajic.2013.12.009

5. Chen JK-H, Chen T-H, Liu H-E (Sarah), Kao C-C, (Cliff) Chen CF, Ou T-Y, et al. Bundle Care for Preventing Ventilator-associated Pneumonia at a Medical Center: A Preliminary Report. J Exp Clin Med. 2014;6(5):157-60. doi: 10.1016/j.jecm.2014.08.003

6. Fihman V, Messika J, Hajage D, Tournier V, Gaudry S, Magdoud F, et al. Five-year trends for ventilator-associated pneumonia: Correlation between microbiological findings and antimicrobial drug consumption. Int J Antimicrob Agents. 2015;46(5):518-25. doi: 10.1016/j.ijantimicag.2015.07.010

7. Hudson JKC, McDonald BJ, MacDonald JC, Ruel MA, Hudson CCC. Impact of subglottic suctioning on the incidence of pneumonia after cardiac surgery: A retrospective observational study. J Cardiothorac Vasc Anesth. 2015;29(1):59-63. doi: 10.1053/j.jvca.2014.04.026

8. Mohamed KAE. Compliance with VAP bundle implementation and its effectiveness on surgical and medical sub-population in adult ICU. Egypt J Chest Dis Tuberc. 2014;63(1):9-14. doi: 10.1016/j.ejcdt.2013.10.019

9. Dey A, Bairy I. Incidence of multidrug-resistant organisms causing ventilator-associated pneumonia in a tertiary care hospital: A nine months' prospective study. Ann Thorac Med. 2007;2(2):52-7. doi: 10.4103/1817-1737.32230

10. Memish ZA, Cunningham G, Oni GA, Djazmati W. The incidence and risk factors of ventilator-associated pneumonia in a Riyadh hospital. Infect Control Hosp Epidemiol. 2000;21(4):271-3. doi: 10.1086/501758

11. Rosenthal VD. Device-associated nosocomial infections in limited-resources countries: findings of the International Nosocomial Infection Control Consortium (INICC). Am J Infect Control. 2008;36(10):S171.e7-12. doi: 10.1016/j.ajic.2008.10.009

12. Guanche-Garcell H, Requejo-Pino O, Rosenthal VD, Morales-Pérez C, Delgado-González O, Fernández-González D. Device-associated infection rates in adult intensive care units of Cuban university hospitals: International Nosocomial Infection Control Consortium (INICC) findings. Int $\mathrm{J}$ Infect Dis. 2011;15(5):e357-62. doi: 10.1016/j.ijid.2011.02.001

13. Melsen WG, Rovers MM, Groenwold RHH, Bergmans DCJJ, Camus C, Bauer TT, et al. Attributable mortality of ventilator-associated pneumonia: a meta-analysis of individual patient data from randomised prevention studies. Lancet Infect Dis. 2013;13(8):665-71. doi: 10.1016/S14733099(13)70081-1

14. Sharpe JP, Magnotti LJ, Weinberg JA, Swanson JM, Wood GC, Fabian TC, et al. Impact of pathogen-directed antimicrobial therapy for ventilatorassociated pneumonia in trauma patients on charges and recurrence. J Am Coll Surg. 2015;220(4):489-95. doi: 10.1016/j.jamcollsurg.2014.12.016

15. Kollef MH, Hamilton CW, Ernst FR. Economic impact of ventilator-associated pneumonia in a large matched cohort. Infect Control Hosp Epidemiol. 2012;33(3):250-6. doi: 10.1086/664049

16. Micek ST, Wunderink RG, Kollef MH, Chen C, Rello J, Chastre J, et al. An international multicenter retrospective study of Pseudomonas aeruginosa nosocomial pneumonia: Impact of multidrug resistance. Crit Care. 2015;19:219. doi: 10.1186/s13054-015-0926-5

17. Garnacho-Montero J, Ortiz-Leyba C, Fernández-Hinojosa E, Aldabó-Pallás T, Cayuela A, Marquez-Vácaro JA, et al. Acinetobacter baumannii ventilator-associated pneumonia: epidemiological and clinical findings. Intensive Care Med. 2005;31(5):649-55. doi: 10.1007/s00134-0052598-0

18. Inchai J, Pothirat C, Liwsrisakun C, Deesomchok A, Kositsakulchai W, Chalermpanchai N. Ventilator-associated pneumonia: epidemiology and prognostic indicators of 30-day mortality. Jpn J Infect Dis. 2015;68(3):181-6. doi: 10.7883/yoken.JJID.2014.282

19. Čiginskienè A, Dambrauskienè A, Rello J, Adukauskienè D. Ventilator-associated pneumonia due to drug-resistant Acinetobacter baumannii: Risk factors and mortality relation with resistance profiles, and independent predictors of in-hospital mortality. Medicina (B Aires). 2019;55(2):49. doi: 10.3390/medicina55020049

20. Melsen WG, Rovers MM, Koeman M, Bonten MJM. Estimating the attributable mortality of ventilator-associated pneumonia from randomized prevention studies. Crit Care Med. 2011;39(12):2736-42. doi: 10.1097/CCM.0b013e3182281f33

21. Nguile-Makao M, Zahar J-R, Français A, Tabah A, Garrouste-Orgeas M, Allaouchiche B, et al. Attributable mortality of ventilator-associated pneumonia: Respective impact of main characteristics at ICU admission and VAP onset using conditional logistic regression and multi-state models. Intensive Care Med. 2010;36(5):781-9. doi: 10.1007/s00134-010-1824-6

22. Torres A, Niederman MS, Chastre J, Ewig S, Fernandez-Vandellos P, Hanberger H, et al. International ERS/ESICM/ESCMID/ALAT guidelines for the management of hospital-acquired pneumonia and ventilator-associated pneumonia: Guidelines for the management of hospital-acquired pneumonia (HAP)/ventilator-associated pneumonia (VAP) of the European. Eur Respir J. 2017;50(3):1700582. doi: 10.1183/13993003.005822017

23. Magret M, Amaya-Villar R, Garnacho J, Lisboa T, Díaz E, Dewaele J, et al. Ventilator-associated pneumonia in trauma patients is associated with lower mortality: Results from EU-VAP study. J Trauma. 2010;69(4):849-54. doi: 10.1097/TA.0b013e3181e4d7be

24. Eom JS, Lee M-S, Chun H-K, Choi HJ, Jung S-Y, Kim Y-S, et al. The impact of a ventilator bundle on preventing ventilator-associated pneumonia: a multicenter study. Am J Infect Control. 2014;42(1):34-7. doi: 10.1016/j.ajic.2013.06.023

25. Resar R, Pronovost P, Haraden C, Simmonds T, Rainey T, Nolan T. Using a bundle approach to improve ventilator care processes and reduce ventilator-associated pneumonia. Jt Comm J Qual patient Saf. 2005;31(5):243-8. doi: 10.1016/s1553-7250(05)31031-2

Page 7/15 
26. Samra SR, Sherif DM, Elokda SA. Impact of VAP bundle adherence among ventilated critically ill patients and its effectiveness in adult ICU. Egypt J Chest Dis Tuberc. 2017;66(1):81-6. doi: 10.1016/j.ejcdt.2016.08.010

27. Waterer GW. The diagnostic dilemma in suspected ventilator-associated pneumonia. Chest. 2003;123(2):335-7. doi: 10.1378/chest.123.2.335

28. Ego A, Preiser J-C, Vincent J-L. Impact of diagnostic criteria on the incidence of ventilator-associated pneumonia. Chest. 2015;147(2):347-55. doi: $10.1378 /$ chest.14-0610

29. Kirtland SH, Corley DE, Winterbauer RH, Springmeyer SC, Casey KR, Hampson NB, et al. The diagnosis of ventilator-associated pneumonia. Chest. 1997;112(2):445-57. doi: 10.1378/chest.112.2.445

30. Fabregas N, Torres A, El-Ebiary M, Ramirez J, Hernandez C, Gonzalez J, et al. Histopathologic and microbiologic aspects of ventilator-associated pneumonia. Anesthesiology. 1996;84(4):760-71. doi: 10.1136/thx.54.10.867

31. Baselski VS, El-Torky M, Coalson JJ, Griffin JP. The standardization of criteria for processing and interpreting laboratory specimens in patients with suspected ventilator-associated pneumonia. Chest. 1992;102(5):571S-579S. doi: 10.1378/chest.102.5_Supplement_1.571S

32. Stewart NI, Cuthbertson BH. The problems diagnosing ventilator-associated pneumonia. J Intens Care Soc. 2009;10(4):266-72.

33. National Healthcare Safety Network. Ventilator Associated Event (VAE). United States Center for Disease Control and Prevention; $2020: 1-49$. Available at: https://www.cdc.gov/nhsn/pdfs/pscmanual/10-vae_final.pdf. (Accessed 12/21/2019).

34. Pugin J, Auckenthaler R, Mili N, Janssens JP, Lew PD, Suter PM. Diagnosis of ventilator-associated pneumonia by bacteriologic analysis of bronchoscopic and nonbronchoscopic "blind" bronchoalveolar lavage fluid. Am Rev Respir Dis. 1991;143(5 Pt 1):1121-9. doi: 10.1164/ajrccm/143.5_Pt_1.1121

35. Hospital in Europe Link for Infection Control through Surveillance (HELICS). Surveillance of Nosocomial Infections in Intensive Care Units. Protocol, Version 6.1. Scientific Institute of Public Health. Brussels; 2004:1-51. Available at: https://www.sicsag.scot.nhs.uk/hai/helics_protocol.pdf. (Accessed on 01/18/2020).

36. Johanson WG, Pierce AK, Sanford JP, Thomas GD. Nosocomial respiratory infections with gram-negative bacilli. The significance of colonization of the respiratory tract. Ann Intern Med. 1972;77(5):701-6. doi: 10.7326/0003-4819-77-5-701

37. Miller PR, Meredith JW, Chang MC. Optimal threshold for diagnosis of ventilator-associated pneumonia using bronchoalveolar lavage. J Trauma. 2003;55(2):263-7. doi: 10.1097/01.TA.0000075786.19301.91

38. Afify MH, Shaheen EA, El-Dahdouh SS, El-Feky HM. Comparison between bronchoscopic BAL and non-bronchoscopic BAL in patients with VAP. Egypt J Chest Dis Tuberc. 2016;65(1):113-9. doi: 10.1016/j.ejcdt.2015.08.001

39. Fernando SM, Tran A, Cheng W, Klompas M, Kyeremanteng K, Mehta S, et al. Diagnosis of ventilator-associated pneumonia in critically ill adult patients-a systematic review and meta-analysis. Intensive Care Med. 2020;46(6):1170-9. doi: 10.1007/s00134-020-06036-z

40. Tejerina E, Esteban A, Fernández-Segoviano P, Frutos-Vivar F, Aramburu J, Ballesteros D, et al. Accuracy of clinical definitions of ventilatorassociated pneumonia: Comparison with autopsy findings. J Crit Care. 2010;25(1):62-8. doi: 10.1016/j.jcrc.2009.05.008

41. Gürgün A, Korkmaz Ekren P, Bacakoğlu F, Başoğlu OK, Dirican N, Aydemir Ş, et al. The role of endotracheal aspiration in the diagnosis of ventilator associated pneumonia. Tuberk Toraks. 2013;61(4):288-94. Turkish. doi: 10.5578/tt.6610

42. Fàbregas N, Ewig S, Torres A, El-Ebiary M, Ramirez J, de La Bellacasa JP, et al. Clinical diagnosis of ventilator associated pneumonia revisited: comparative validation using immediate post-mortem lung biopsies. Thorax. 1999;54(10):867-73. doi: 10.1136/thx.54.10.867

43. Flanagan PG, Findlay GP, Magee JT, lonescu A, Barnes RA, Smithies M. The diagnosis of ventilator-associated pneumonia using nonbronchoscopic, non-directed lung lavages. Intensive Care Med. 2000;26(1):20-30. doi: 10.1007/s001340050007

44. Corley DE, Kirtland SH, Winterbauer RH, Hammar SP, Dail DH, Bauermeister DE, et al. Reproducibility of the histologic diagnosis of pneumonia among a panel of four pathologists. Chest. 1997;112(2):458-65. doi: 10.1378/chest.112.2.458

45. Mathur P, Tak V, Janani S, Kumar S, Bagla R, Misra M, et al. Diagnosis of ventilator-associated pneumonia: Comparison between ante-mortem and post-mortem cultures in trauma patients. Indian J Med Micro. 2014;32(3):294-300. doi: 10.4103/0255-0857.136572

46. Ramírez-Estrada S, Lagunes L, Peña-López Y, Vahedian-Azimi A, Nseir S, Arvaniti K, et al. Assessing predictive accuracy for outcomes of ventilator-associated events in an international cohort: The EUVAE study. Intensive Care Med. 2018;44(8):1212-20. doi: 10.1007/s00134-0185269-7

47. Pham TN, Neff MJ, Simmons JM, Gibran NS, Heimbach DM, Klein MB. The clinical pulmonary infection score poorly predicts pneumonia in patients with burns. J Burn Care Res. 2007;28(1):76-9. doi: 10.1097/BCR.0b013E31802C88DB

48. Pieracci FM, Rodil M, Haenel J, Stovall RT, Johnson JL, Burlew CC, et al. Screening for ventilator-associated pneumonia in the surgical intensive care unit: A single-institution analysis of 1,013 lower respiratory tract cultures. Surg Infect (Larchmt). 2015;16(4):368-74. doi: 10.1089/sur.2014.086

49. Stevenson KB, Khan Y, Dickman J, Gillenwater T, Kulich P, Myers C, et al. Administrative coding data, compared with CDC/NHSN criteria, are poor indicators of health care-associated infections. Am J Infect Control. 2008;36(3):155-64. doi: 10.1016/j.ajic.2008.01.004

50. Wolfensberger A, Meier AH, Kuster SP, Mehra T, Meier M-T, Sax H. Should International Classification of Diseases codes be used to survey hospital-acquired pneumonia? J Hosp Infect. 2018;99(1):81-4. doi: 10.1016/j.jhin.2018.01.017

Page 8/15 
51. Li B, Zhao X, Li S. Serum Procalcitonin Level and Mortality Risk in Critically ill Patients with Ventilator-Associated Pneumonia. Cell Physiol Biochem. 2015;37(5):1967-72. doi: 10.1159/000438557

52. Sotillo-Díaz JC, Bermejo-López E, García-Olivares P, Peral-Gutiérrez JA, Sancho-González M, Guerrero-Sanz JE. Role of plasma procalcitonin in the diagnosis of ventilator-associated pneumonia: systematic review and metaanalysis. Med intensiva. 2014;38(6):337-46. Spanish. doi:10.1016/j.medin.2013.07.001

53. Kalil AC, Metersky ML, Klompas M, Muscedere J, Sweeney DA, Palmer LB, et al. Management of Adults With Hospital-acquired and Ventilatorassociated Pneumonia: 2016 Clinical Practice Guidelines by the Infectious Diseases Society of America and the American Thoracic Society. Clin Infect Dis. 2016;63(5):e61-111. doi: 10.1093/cid/ciw353

54. Jung B, Embriaco N, Roux F, Forel J-M, Demory D, Allardet-Servent J, et al. Microbiogical data, but not procalcitonin improve the accuracy of the clinical pulmonary infection score. Intensive Care Med. 2010;36(5):790-8. doi: 10.1007/s00134-010-1833-5

55. Pinzone MR, Cacopardo B, Abbo L, Nunnari G. Optimal duration of antimicrobial therapy in ventilator-associated pneumonia: What is the role for procalcitonin? J Glob Antimicrob Resist. 2014;2(4):239-44. doi: 10.1016/j.jgar.2014.06.004

56. Stolz D, Smyrnios N, Eggimann P, Pargger H, Thakkar N, Siegemund M, et al. Procalcitonin for reduced antibiotic exposure in ventilatorassociated pneumonia: a randomised study. Eur Respir J. 2009;34(6):1364-75. doi: 10.1183/09031936.00053209

57. White RG, Hakim AJ, Salganik MJ, Spiller MW, Johnston LG, Kerr L, et al. Strengthening the Reporting of Observational Studies in Epidemiology for respondent-driven sampling studies: “STROBE-RDS” statement. J Clin Epidemiol. 2015;68(12):1463-71. doi: 10.1016/j.jclinepi.2015.04.002

58. Xie D, Xiong W, Lai R, Liu L, Gan X, Wang X, et al. Ventilator-associated pneumonia in intensive care units in Hubei Province, China: A multicentre prospective cohort survey. J Hosp Infect. 2011;78(4):284-8. doi: 10.1016/j.jhin.2011.03.009

59. López-Pueyo MJ, Olaechea-Astigarraga P, Palomar-Martínez M, Insausti-Ordeñana J, Alvarez-Lerma F, ENVIN-HELICS Study Group. Quality control of the surveillance programme of ICU-acquired infection (ENVIN-HELICS registry) in Spain. J Hosp Infect. 2013;84(2):126-31. doi: 10.1016/j.jhin.2013.02.018

60. Duszyńska W, Barteczko B, Kübler A. Monitoring of nosocomial infections using the HELICS network. Anestezjol Intens Ter. 2008;40(1):17-21.

61. Álvarez Lerma F, Carrasco M, Otal JJ, Palomar M, Olaechea P, Peris X, et al. Invasive device-related infections after heart surgery. Med Intensiva. 2013;37(9):584-92. doi: 10.1016/j.medin.2012.12.005

62. Bouadma L, Luyt C-E, Tubach F, Cracco C, Alvarez A, Schwebel C, et al. Use of procalcitonin to reduce patients' exposure to antibiotics in intensive care units (PRORATA trial): A multicentre randomised controlled trial. Lancet. 2010;375(9713):463-74. doi: 10.1016/S01406736(09)61879-1

63. Torres A, El-Ebiary M, Padró L, Gonzalez J, de la Bellacasa JP, Ramirez J, et al. Validation of different techniques for the diagnosis of ventilatorassociated pneumonia. Comparison with immediate postmortem pulmonary biopsy. Am J Respir Crit Care Med. 1994;149(2 Pt 1):324-31. doi: 10.1164/ajrccm.149.2.8306025

64. Jiao J, Wang M, Zhang J, Shen K, Liao X, Zhou X. Procalcitonin as a diagnostic marker of ventilator-associated pneumonia in cardiac surgery patients. Exp Ther Med. 2015;9(3):1051-7. doi: 10.3892/etm.2015.2175

65. Jamaati HR, Malekmohammad M, Hashemian MR, Nayebi M, Barsharzad N. Ventilator-associated pneumonia: Evaluation of etiology, microbiology and resistance patterns in a tertiary respiratory center. Tanaffos. 2010;9(1):21-7.

66. Chittawatanarat K, Jaipakdee W, Chotirosniramit N, Chandacham K, Jirapongcharoenlap T. Microbiology, resistance patterns, and risk factors of mortality in ventilator-associated bacterial pneumonia in a Northern Thai tertiary-care university based general surgical intensive care unit. Infect Drug Resist. 2014;7:203-10. doi: 10.2147/IDR.S67267

67. Bloos F, Marshall JC, Dellinger RP, Vincent J-L, Gutierrez G, Rivers E, et al. Multinational, observational study of procalcitonin in ICU patients with pneumonia requiring mechanical ventilation: a multicenter observational study. Crit Care. 2011;15(2):R88. doi: 10.1186/cc10087

68. Karhu J, Ala-Kokko TI, Ylipalosaari P, Ohtonen P, Laurila JJ, Syrjala H. Hospital and long-term outcomes of ICU-treated severe community- and hospital-acquired, and ventilator-associated pneumonia patients. Acta Anaesthesiol Scand. 2011;55(10):1254-60. doi: 10.1111/j.13996576.2011.02535.x

69. Hedrick TL, Smith RL, McElearney ST, Evans HL, Smith PW, Pruett TL, et al. Differences in early-and late-onset ventilator-associated pneumonia between surgical and trauma patients in a combined surgical or trauma intensive care unit. J Trauma Inj Infect Crit Care. 2008;64(3):714-20. doi: 10.1097/TA.0b013e31811ec18e

70. Vallés J, Pobo A, García-Esquirol O, Mariscal D, Real J, Fernández R. Excess ICU mortality attributable to ventilator-associated pneumonia: The role of early vs late onset. Intensive Care Med. 2007;33(8):1363-8. doi: 10.1007/s00134-007-0721-0

71. Giard M, Lepape A, Allaouchiche B, Guerin C, Lehot J-J, Robert M-O, et al. Early- and late-onset ventilator-associated pneumonia acquired in the intensive care unit: comparison of risk factors. J Crit Care. 2008;23(1):27-33. doi: 10.1016/j.jcrc.2007.08.005

72. Restrepo MI, Peterson J, Fernandez JF, Qin Z, Fisher AC, Nicholson SC. Comparison of the bacterial etiology of early-onset and late-onset ventilator-associated pneumonia in subjects enrolled in 2 large clinical studies. Respir Care. 2013;58(7):1220-5. doi: 10.4187/respcare.02173

73. Pawar M, Mehta Y, Khurana P, Chaudhary A, Kulkarni V, Trehan N. Ventilator-associated pneumonia: Incidence, risk factors, outcome, and microbiology. J Cardiothorac Vasc Anesth. 2003;17(1):22-8. doi: 10.1053/jcan.2003.4

Page 9/15 
74. Japoni A, Vazin A, Davarpanah MA, Afkhami Ardakani M, Alborzi A, Japoni S, et al. Ventilator-associated pneumonia in Iranian intensive care units. J Infect Dev Ctries. 2011;5(04):286-93. doi: 10.3855/jidc.1212

75. Parker CM, Kutsogiannis J, Muscedere J, Cook D, Dodek P, Day AG, et al. Ventilator-associated pneumonia caused by multidrug-resistant organisms or Pseudomonas aeruginosa: Prevalence, incidence, risk factors, and outcomes. J Crit Care. 2008;23(1):18-26. doi: 10.1016/j.jcrc.2008.02.001

76. Sundar KM, Nielsen D, Sperry P. Comparison of ventilator-associated pneumonia (VAP) rates between different ICUs: Implications of a zero VAP rate. J Crit Care. 2012;27(1):26-32. doi: 10.1016/j.jcrc.2011.05.019

77. Giantsou E, Liratzopoulos N, Efraimidou E, Panopoulou M, Alepopoulou E, Kartali-Ktenidou S, et al. Both early-onset and late-onset ventilatorassociated pneumonia are caused mainly by potentially multiresistant bacteria. Intensive Care Med. 2005;31(11):1488-94. doi: $10.1007 /$ s00134-005-2697-y

78. Ibrahim EH, Tracy L, Hill C, Fraser VJ, Kollef MH. The occurrence of ventilator-associated pneumonia in a community hospital. Chest. 2001;120(2):555-61. doi: 10.1378/chest.120.2.555

79. Rezai MS, Bagheri-Nesami M, Nikkhah A, Bayg AHA. Incidence, risk factors, and outcome of ventilator-associated pneumonia in 18 hospitals of Iran. Int J Adv Biotech Res. 2016;7(3):936-46.

80. Chouhdari A, Shokouhi S, Bashar FR, Vahedian-Azimi A, Shojaei SP, Fathi M, et al. Is a low incidence rate of ventilation associated pneumonia associated with lower mortality? A descriptive longitudinal study in Iran. Tanaffos. 2018;17(2):110-6.

81. Waltrick R, Possamai DS, Aguiar FP de, Dadam M, Souza Filho VJ de, Ramos LR, et al. Comparison between a clinical diagnosis method and the surveillance technique of the Center for Disease Control and Prevention for identification of mechanical ventilator-associated pneumonia. Rev Bras Ter Intensiva. 2015;27(3):260-5. doi: 10.5935/0103-507X.20150047

82. Pham DT, Nguyen TN, Do Q. Researching the changes of serum procalcitonin levels in ventilator-associated pneumonia patients. Mycobact Dis. 2017;07(03):1000246. doi: 10.4172/2161-1068.1000246

83. Yagmurdur $\mathrm{H}$, Tezcan AH, Karakurt O, Leblebici $\mathrm{F}$. The efficiency of routine endotracheal aspirate cultures compared to bronchoalveolar lavage cultures in ventilator-associated pneumonia diagnosis. Niger J Clin Pract. 2016;19(1):46-51. doi: 10.4103/1119-3077.164327

84. Seligman R, Seligman BGS, Konkewicz L, Dos Santos RP. Accuracy of tracheal aspirate gram stain in predicting Staphylococcus aureus infection in ventilator-associated pneumonia. BMC Anesthesiol. 2015;15(1):19. doi: 10.1186/1471-2253-15-19

85. Schurink CAM, Nieuwenhoven CA Van, Jacobs JA, Rozenberg-Arska M, Joore HCA, Buskens E, et al. Clinical pulmonary infection score for ventilator-associated pneumonia: accuracy and inter-observer variability. Intensive Care Med. 2004;30(2):217-24. doi:10.1007/s00134-0032018-2

86. Luyt C-E, Chastre J, Fagon J-Y. Value of the clinical pulmonary infection score for the identification and management of ventilator-associated pneumonia. Intensive Care Med. 2004;30(5):844-52. doi:10.1007/s00134-003-2125-0

87. Quick JA, Breite MD, Barnes SL. Inadequacy of algorithmic ventilator-associated pneumonia diagnosis in acute care surgery. Am Surg. 2018;84(2):300-4.

88. Leonard KL, Borst GM, Davies SW, Coogan M, Waibel BH, Poulin NR, et al. Ventilator-associated pneumonia in trauma patients: Different criteria, different rates. Surg Infect. 2016;17(3):363-8. doi:10.1089/sur.2014.076

\section{Tables}

Table 1. Ventilator-associated pneumonia diagnostic algorithms utilized in this study. 


\begin{tabular}{|c|c|c|c|c|}
\hline & $\begin{array}{l}\text { Systemic } \\
\text { Criteria }\end{array}$ & Chest Criteria & Chest Radiography Criteria & Microbiologic Criteria \\
\hline \multirow[t]{2}{*}{$\overline{\mathrm{IHSN}}(33)$} & $\begin{array}{l}\text { Inflammatory } \\
\text { response } \\
\text { Temperature } \\
>38^{\circ} \mathrm{C} \\
\text { WBC } \\
>12,000 / \mathrm{mm}^{3} \\
\text { or } \\
<4,000 / \mathrm{mm}^{3} \\
- \text { OR new } \\
\text { antimicrobial } \\
\text { agent is } \\
\text { started for } \\
\geq 4 \text { days } \\
\rightarrow \text { Infection- } \\
\text { related } \\
\text { ventilator- } \\
\text { associated } \\
\text { complication }\end{array}$ & $\begin{array}{l}\text { After a period of stability or } \\
\text { improvement on the } \\
\text { ventilator ( } \geq 2 \text { calendar days } \\
\text { of stable or } \downarrow \mathrm{F}_{\mathrm{i}} \mathrm{O}_{2} \text { or PEEP): } \\
\text { - Minimum daily } \mathrm{F}_{\mathrm{i}} \mathrm{O}_{2} \uparrow \geq 0.20 \\
\text { lasting } 2 \text { days } \\
\text { - Or minimum daily PEEP } \\
\text { values } \uparrow \geq 3 \mathrm{~cm} \mathrm{H}_{2} \mathrm{O} \text { lasting } 2 \\
\text { days } \\
\rightarrow \text { Ventilator-associated } \\
\text { condition }\end{array}$ & ---- & $\begin{array}{l}\text { Microbiologic quantitative (+), OR } \\
\text { histologic }(+) \text {, OR }(+) \text { for legionella, } \\
\text { influenza, RSV, adenovirus, or } \\
\text { parainfluenza virus } \\
\text { AND } \\
\text { Gram-stain evidence } \geq 25 \text { neutrophils/lpf } \\
\text { and } \leq 10 \text { epithelial cells/lpf } \\
\rightarrow \text { Probable VAP }\end{array}$ \\
\hline & $\begin{array}{l}\text { Fever: } \\
-38.5-38.9(1 \\
\text { point) } \\
-\geq 39 \text { or } \\
<36.5(2 \\
\text { points) } \\
\text { WBC: } \\
-<4,000 / \mathrm{mm}^{3} \\
\text { or } \\
>11,000 / \mathrm{mm}^{3} \\
(2 \text { points })\end{array}$ & $\begin{array}{l}\text { - Secretions but not purulent } \\
\text { ( } 1 \text { point) } \\
\text { - Purulent secretions ( } 2 \\
\text { points) } \\
-\mathrm{P}_{\mathrm{a}} \mathrm{O}_{2} / \mathrm{F}_{\mathrm{i}} \mathrm{O}_{2}<240 \text { without } \\
\text { ARDS ( } 2 \text { points) }\end{array}$ & $\begin{array}{l}\text { Diffuse infiltrate (1 point) } \\
\text { Localized infiltrate ( } 2 \text { points) } \\
\text { Progressive infiltrate (without cardiac } \\
\text { disease or ARDS) ( }+2 \text { ) }\end{array}$ & Positive (1 point) \\
\hline$\overline{\mathrm{S}^{\mathrm{b}}}$ & 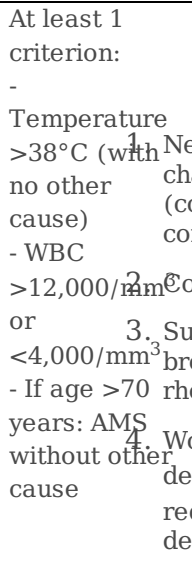 & $\begin{array}{l}\text { At least } 1 \text { of following } \\
\text { criteria ( } 2 \text { clinical pneumonia } \\
\text { only = PN4 and PN5): } \\
\text { w onset purulent sputum or } \\
\text { ange in sputum character } \\
\text { lor, odor, quantity, } \\
\text { psistency) } \\
\text { ugh or dyspnea or tachypnea } \\
\text { ggestive auscultation (rales or } \\
\text { pnchial breath sounds, } \\
\text { pnchi, wheezing) } \\
\text { prsening gas exchange }\left(\mathrm{O}_{2}\right. \\
\text { saturation, increasing } \mathrm{F}_{\mathrm{i}} \mathrm{O}_{2} \\
\text { quirements or ventilation } \\
\text { mands) }\end{array}$ & $\begin{array}{l}\text { Image suggestive of pneumonia. ( } \geq 2 \\
\text { serial chest X-rays or CT scans with } \\
\text { suggestive imaging for patients with } \\
\text { underlying cardiac or pulmonary disease) }\end{array}$ & $\begin{array}{l}\text { I1 - (+) quantitative Cx from } \\
\text { nimally contaminated LRT specimen }{ }^{\mathrm{C}} \\
\text { T2 - (+) quantitative Cx from possibly } \\
\text { ntaminated LRT specimen }{ }^{d} \\
\text { T3 - Alternative methods: }{ }^{\text {e }}(+) \text { blood } \\
\text { pleural Cx, pleural or pulmonary } \\
\text { Scess, histology, or pathogen antigen } \\
\text { antibody testing. } \\
\text { I4 - (+) sputum Cx or non-quantitative LRT } \\
\text { ecimen Cx } \\
\text { T5 - No positive results }\end{array}$ \\
\hline on & $\begin{array}{l}\text { Temperature } \\
>38.5^{\circ} \mathrm{C} \\
\mathrm{WBC} \\
>12,000 / \mathrm{mm}^{3}\end{array}$ & Purulent secretions & New or progressive consolidation & --- \\
\hline
\end{tabular}

\section{a Score $>6$ is suggestive of VAP.}

$\mathrm{b}$ VAP diagnosis if criteria met and invasive respiratory device (even intermittently) in the 48 hours preceding the onset of infection.

C Either: (1) Broncho-alveolar lavage (BAL) with a threshold of $\geq 104 \mathrm{cfu} / \mathrm{mL}$ or $\geq 5 \%$ of BAL obtained cells contains intracellular bacteria on direct microscopic exam; (2) Protected brush (PB Wimberley) with a threshold of $\geq 103 \mathrm{cfu} / \mathrm{mL}$; (3) Distal protected aspirate (DPA) with a threshold of $\geq 103 \mathrm{cfu} / \mathrm{mL}$.

d Quantitative culture of LRT specimen (e.g., endotracheal aspirate) with a threshold of $106 \mathrm{cfu} / \mathrm{mL}$.

e Either: (1) positive blood culture not related to another source of infection; (2) positive growth in culture of pleural fluid; (3) pleural or pulmonary exam shows evidence of pneumonia; (4) positive exams for pneumonia with virus or particular germs (Legionella, Aspergillus, mycobacteria, Mycoplasma, Pneumocystis carinii) . The latter may include: (A) positive detection of viral antigen or antibody from respiratory secretions (e.g., EIA, FAMA, shell vial assay, PCR); (B) positive direct exam or positive culture from bronchial secretions or tissue; (C) seroconversion (ex: influenza viruses, Legionella, Chlamydia); or (D) detection of antigens in urine (Legionella). 
AMS: altered mental status; ARDS: acute respiratory distress syndrome; CDC/NHSN: centers for disease control and prevention national health safety network; CPIS: clinical pulmonary infection score; Cx: culture; $\mathrm{F}_{\mathrm{i}} \mathrm{O}_{2}$ : fraction of inspired oxygen; HELICS: hospital in Europe link for infection control through surveilance; LRT: lower respiratory tract; $\mathrm{P}_{\mathrm{a}} \mathrm{O}_{2}$ : partial pressure of oxygen in arterial blood; RSV: respiratory syncytial virus; VAP: ventilator associated pneumonia; WBC: white blood cell

Table 2. Performance characteristics of ventilator-associated pneumonia diagnostic algorithms.

\begin{tabular}{|c|c|c|c|c|c|c|c|c|c|c|c|c|}
\hline $\begin{array}{l}\text { Criteria } \\
\text { Studied }\end{array}$ & $\begin{array}{l}\text { Year, } \\
\text { (citation) }\end{array}$ & Population & Comparator & $\begin{array}{l}\text { Sample } \\
\text { Size }\end{array}$ & Sensitivity & Specificity & PPV & NPV & $\begin{array}{l}(+) \\
\mathrm{LR}\end{array}$ & $\begin{array}{l}-(-) \\
L R\end{array}$ & $\begin{array}{l}\text { ROC } \\
\text { AUC }\end{array}$ & $\begin{array}{l}\text { Kappa () } \\
\text { index, } \\
\text { agreement } \\
\text { level a }^{\text {a }}\end{array}$ \\
\hline CDC/NHSN & $\begin{array}{l}\text { 2015, } \\
(81)\end{array}$ & Mixed $^{b}$ & CPIS & 38 & 0.37 & 1.0 & 1.0 & 0.84 & & & & $\begin{array}{l}\mathrm{q}=0.47 \\
\text { moderate }\end{array}$ \\
\hline CPIS & $\begin{array}{l}1999, \\
(42)\end{array}$ & Mixed $^{b}$ & Pathology & 23 & 0.77 & 0.42 & & & & & & \\
\hline $\mathrm{CPIS}^{\mathrm{c}}$ & $\begin{array}{l}2004, \\
(85)\end{array}$ & Mixed ${ }^{b}$ & $\begin{array}{l}\text { Quantitative } \\
\text { Cultures }\end{array}$ & 69 & 0.41 & 0.77 & 0.8 & 0.36 & & & 0.64 & \\
\hline CPIS & $\begin{array}{l}2004, \\
(86)\end{array}$ & Mixed $^{b}$ & $\begin{array}{l}\text { Quantitative } \\
\text { Cultures }\end{array}$ & 88 & 0.89 & 0.47 & 0.57 & 0.84 & & & & $\begin{array}{l}\square=0.33, \\
\text { fair }\end{array}$ \\
\hline CPIS & $\begin{array}{l}2007 \\
(47)\end{array}$ & Burn & $\begin{array}{l}\text { Quantitative } \\
\text { Cultures }\end{array}$ & 28 & 0.30 & 0.80 & 0.70 & 0.50 & & & & \\
\hline CPIS & $\begin{array}{l}2010, \\
(40)\end{array}$ & Mixed ${ }^{b}$ & Pathology & 142 & 0.46 & 0.60 & & & 1.13 & 0.96 & & \\
\hline CPIS & $\begin{array}{l}2015, \\
(48)\end{array}$ & $\begin{array}{l}\text { Surgical } \\
\text { (mixed) }\end{array}$ & $\begin{array}{l}\text { Quantitative } \\
\text { Cultures }\end{array}$ & 497 & 0.633 & 0.644 & 0.61 & 0.674 & & & 0.60 & \\
\hline CPIS & $\begin{array}{l}\text { 2018, } \\
(87)\end{array}$ & $\begin{array}{l}\text { Surgical } \\
\text { (acute } \\
\text { care) }\end{array}$ & $\begin{array}{l}\text { Quantitative } \\
\text { Cultures }\end{array}$ & 198 & 0.611 & 0.781 & 0.64 & 0.759 & & & & \\
\hline HELICS & $\begin{array}{l}\text { 2013, } \\
(59)\end{array}$ & Mixed $^{b}$ & $\begin{array}{l}\text { Not clearly } \\
\text { specified }\end{array}$ & $57^{d}$ & 0.86 & 0.99 & 0.77 & 0.995 & & & & $\begin{array}{l}=0.80, \\
\text { substantial }\end{array}$ \\
\hline Johansen $^{\mathrm{e}}$ & $\begin{array}{l}\text { 1999, } \\
(42)\end{array}$ & Mixed $^{b}$ & Pathology & 23 & 0.69 & 0.75 & & & & & & \\
\hline Johansen & $\begin{array}{l}\text { 2018, } \\
\text { (87) }\end{array}$ & $\begin{array}{l}\text { Surgical } \\
\text { (acute } \\
\text { care) }\end{array}$ & $\begin{array}{l}\text { Quantitative } \\
\text { Cultures }\end{array}$ & 198 & 0.828 & 0.59 & 0.564 & 0.843 & & & & \\
\hline NTDB/NTR & $\begin{array}{l}\text { 2015, } \\
(88)\end{array}$ & Trauma & CDC/NHSN & 279 & 0.864 & 0.578 & 0.74 & 0.74 & & & & $\begin{array}{l}\mathrm{q}=0.47 \\
\text { moderate }\end{array}$ \\
\hline
\end{tabular}

a Agreement based on score: $\leq 0$ (no agreement); 0.01-0.20 (slight); 0.21-0.40 (fair); 0.41- 0.60 (moderate); 0.61-0.80 (substantial); and 0.81-1.00 (almost perfect agreement).

b A mixed population containing both medical and surgical patients. Studies that did not specify ICU type were by default classified as mixed.

C For CPIS threshold of $>7$, rather than current standard of $>6$. The AUC using threshold CPIS $>6$ was 0.54 , other values not reported.

d Data from sub-population of a larger study assessing various types of ICU-acquired infections.

e The presence of all three criteria increased the specificity to $92 \%$ at the cost of a high beta error (sensitivity $23 \%$ ).

CDC/NHSN: centers for disease control and prevention national health safety network; ICU: intensive care unit; MV: mechanical ventilation; NR: not reported; NTDB/NTR: national trauma data bank / national trauma registry; NPV: negative predictive value; PPV: positive predictive value; ROC AUC: receiver operating curve area under curve; (+) LR : positive likelihood ratio; (-) LR: negative likelihood ratio

Table 3. Patient demographic and clinical information. 


\begin{tabular}{|c|c|c|c|c|}
\hline Variable & All & $\begin{array}{c}\text { VAP } \\
\mathrm{n}=45\end{array}$ & $\begin{array}{c}\text { No VAP } \\
\mathrm{n}=40\end{array}$ & p-Value \\
\hline Age, years, mean (SD) & $46.9(18.9)$ & $44.2(20.7)$ & $49.9(16.4)$ & $0.159^{\mathrm{a}}$ \\
\hline Male, mean (SD) & $62(72.9)$ & $33(73.3)$ & $29(72.5)$ & $0.931^{\mathrm{c}}$ \\
\hline $\begin{array}{l}\text { Admission indication, N (\%) } \\
\text { Trauma } \\
\text { Post-operative }\end{array}$ & $\begin{array}{ll}54 & (63.5) \\
31 & (36.5)\end{array}$ & $\begin{array}{ll}30 & (66.7) \\
15 & (33.3)\end{array}$ & $\begin{array}{l}24(60) \\
16(40)\end{array}$ & $0.652^{\mathrm{c}}$ \\
\hline $\begin{array}{l}\text { Comorbidities, yes, N (\%) } \\
\text { ARDS } \\
\text { Cancer } \\
\text { COPD } \\
\text { CHF } \\
\text { ESRD } \\
\text { Multiple trauma }\end{array}$ & $\begin{array}{l}7(8.2) \\
13(15.3) \\
7(8.2) \\
24(28.2) \\
14(16.5) \\
20(23.5)\end{array}$ & $\begin{array}{l}3(6.7) \\
6(13.3) \\
4(8.9) \\
13(28.9) \\
9(20) \\
10(22.2)\end{array}$ & $\begin{array}{l}4(10) \\
7(17.5) \\
3(7.5) \\
11(27.5) \\
5(12.5) \\
10(25)\end{array}$ & $0.932^{b}$ \\
\hline Positive tracheal culture, N (\%) & $69(81.2)$ & $40(88.9)$ & $29(72.5)$ & $0.093^{\mathrm{c}}$ \\
\hline MDR organism, yes, N (\%) & $31(36.5)$ & $17(37.8)$ & $14(35)$ & $0.825^{\mathrm{c}}$ \\
\hline Procalcitonin, ng/mL, mean (SD) & $4.03(4.68)$ & $3.53(3.6)$ & $4.6(5.6)$ & $0.308^{a}$ \\
\hline APACHE II, mean (SD) & $18.1(2.84)$ & $17.9(3.43)$ & $18.4(1.98)$ & $0.399^{\mathrm{a}}$ \\
\hline Duration of intubation, hours, mean (SD) & $177.1(39.61)$ & $176.02(38.7)$ & $178.32(41.09)$ & $0.791^{\mathrm{a}}$ \\
\hline Reintubation, N (\%) & $32(37.6)$ & $14(31.1)$ & $18(45)$ & $0.262^{\mathrm{c}}$ \\
\hline MV duration prior to VAP, hours, median (IQR) & $72(54-87.5)$ & $72(52-87.5)$ & $72(64.5-88.5)$ & $0.639^{\mathrm{a}}$ \\
\hline ICU duration prior to developing VAP, days, median (IQR) & $7(6-8)$ & $7(6-8.5)$ & $7(6-8)$ & $0.118^{\mathrm{a}}$ \\
\hline $\begin{array}{c}\text { VAP timing, mean }(\mathrm{SD}) \\
\text { Early }(<5 \text { days }) \\
\text { Late }(\geq 5 \text { days }) \\
\end{array}$ & ------ & $\begin{array}{ll}15 & (33.3) \\
30 & (66.7) \\
\end{array}$ & ------ & $\begin{array}{ll}------ \\
\end{array}$ \\
\hline $\begin{array}{l}\text { Length-of-stay, days, mean (SD) } \\
\text { ICU LOS } \\
\text { Non-ICU LOS }\end{array}$ & $\begin{array}{l}9.8(3.0) \\
15.4(3.1)\end{array}$ & $\begin{array}{l}13.13(3.27) \\
12.67(3.34)\end{array}$ & $\begin{array}{l}12.72(2.75) \\
11.96(2.99)\end{array}$ & $\begin{array}{l}0.538^{\mathrm{a}} \\
0.320^{\mathrm{a}}\end{array}$ \\
\hline $\begin{array}{l}\text { Mortality, N (\%) } \\
\text { ICU } \\
\text { Hospital }\end{array}$ & $\begin{array}{l}17(20) \\
22(25.9)\end{array}$ & $\begin{array}{l}8(17.8) \\
12(26.7)\end{array}$ & $\begin{array}{l}9(22.5) \\
10(25)\end{array}$ & $\begin{array}{l}0.787^{\mathrm{C}} \\
0.861^{\mathrm{c}} \\
\end{array}$ \\
\hline
\end{tabular}

VAP: ventilator-associated pneumonia; IQR: interquartile range; MDR: multiple drug resistant; APACHE: Acute Physiology and Chronic Health Evaluation; ICU: intensive care unit; VAP: ventilator-associated pneumonia; LOS: length-of-stay

${ }^{a}$ Independent sample t-test

${ }^{\mathrm{b}}$ Fisher exact test

${ }^{\mathrm{c}}$ Chi-square

Table 4. Sensitivity, specificity, and Youden index for assessed methods of ventilator-associated pneumonia diagnosis compared to the HELICS criteria as the reference standard.

\begin{tabular}{|c|c|c|c|c|c|c|}
\hline \multirow[t]{2}{*}{ Criteria } & \multicolumn{3}{|c|}{ Ventilator-Associate Pneumonia } & \multirow[t]{2}{*}{ \% Sensitivity } & \multirow[t]{2}{*}{ \% Specificity } & \multirow{2}{*}{ Youden index } \\
\hline & Positive & Negative & Total & & & \\
\hline $\begin{array}{c}\text { CDC/NHSN } \\
\text { Positive } \\
\text { Negative } \\
\text { Total } \\
\end{array}$ & $\begin{array}{l}45 \\
0 \\
45 \\
\end{array}$ & $\begin{array}{l}38 \\
2 \\
40 \\
\end{array}$ & $\begin{array}{l}83 \\
2 \\
85 \\
\end{array}$ & 54.22 & 100 & 0.542 \\
\hline $\begin{array}{ll}\text { CPIS } & \\
& \text { Positive } \\
& \text { Negative } \\
& \text { Total } \\
\end{array}$ & $\begin{array}{l}44 \\
1 \\
45\end{array}$ & $\begin{array}{l}20 \\
20 \\
40\end{array}$ & $\begin{array}{l}64 \\
21 \\
85\end{array}$ & 68.75 & 95.23 & 0.640 \\
\hline $\begin{array}{c}\text { Johanson } \\
\text { Positive } \\
\text { Negative } \\
\text { Total } \\
\end{array}$ & $\begin{array}{l}44 \\
1 \\
45\end{array}$ & $\begin{array}{l}21 \\
19 \\
40\end{array}$ & $\begin{array}{l}65 \\
20 \\
85\end{array}$ & 67.69 & 95 & 0.627 \\
\hline
\end{tabular}

a A measure of the maximum diagnostic accuracy, where 1 signifies a perfect test and 0 signifies no diagnostic value.

$\mathrm{CDC} / \mathrm{NHSN}=$ centers for disease control and prevention national health safety network; CPIS = Clinical Pulmonary Infection Score, HELICS = Hospital in Europe Link for Infection Control through Surveillance.

Table 5. Correlation of serum procalcitonin and tracheal aspirate results with ventilator-associated pneumonia diagnostic algorithms. 


\begin{tabular}{|c|c|c|c|c|c|c|c|c|c|}
\hline \multirow[t]{2}{*}{ Criteria } & \multicolumn{4}{|c|}{ Serum Procalcitonin Level, ng/mL } & \multirow{2}{*}{$\begin{array}{c}\text { Kappa ( } \square \text { ) index, agreement } \\
\text { level }^{\text {a }} \\
\text { (p-Value) }\end{array}$} & \multicolumn{3}{|c|}{ Tracheal Culture } & \multirow{2}{*}{$\begin{array}{c}\text { Kappa () index, agreement } \\
\text { level }^{\mathrm{a}} \\
\text { (p-Value) }\end{array}$} \\
\hline & $<0.25$ & $\begin{array}{c}0.25- \\
0.5\end{array}$ & $>0.5$ & Total & & Positive & Negative & Total & \\
\hline $\begin{array}{c}\text { Johanson, } \mathbf{n}(\%) \\
\text { Positive } \\
\text { Negative } \\
\text { Total }\end{array}$ & $\begin{array}{l}10 \\
(15.4) \\
18(90) \\
28 \\
(32.9)\end{array}$ & $\begin{array}{l}9 \\
(13.8) \\
0 \\
9 \\
(10.6)\end{array}$ & $\begin{array}{l}46 \\
(70.8) \\
2(10) \\
48 \\
(56.5)\end{array}$ & $\begin{array}{l}65 \\
20 \\
85 \\
(100)\end{array}$ & $\begin{array}{l}\text { 0.47, moderate } \\
\qquad(<0.001)\end{array}$ & $\begin{array}{l}61 \\
(93.8) \\
8(40) \\
69 \\
(81.2)\end{array}$ & $\begin{array}{l}4(6.2) \\
12(60) \\
16 \\
(18.8)\end{array}$ & $\begin{array}{l}65 \\
20 \\
85 \\
(100)\end{array}$ & $\begin{array}{l}\text { 0.579, moderate } \\
\quad(<0.001)\end{array}$ \\
\hline $\begin{array}{l}\text { CDC/NHSN, } \mathrm{n} \\
\text { (\%) } \\
\\
\\
\text { Positive } \\
\text { Negative } \\
\text { Total }\end{array}$ & $\begin{array}{l}26 \\
(31.3) \\
2(100) \\
28 \\
(32.9)\end{array}$ & $\begin{array}{l}10 \\
(12.0) \\
0 \\
10 \\
(11.8)\end{array}$ & $\begin{array}{l}47 \\
(56.6) \\
0 \\
47 \\
(55.3)\end{array}$ & $\begin{array}{l}83 \\
2 \\
85 \\
(100)\end{array}$ & $\begin{array}{c}\text { 0.06, slight } \\
\text { (0.58) }\end{array}$ & $\begin{array}{l}67 \\
(80.7) \\
2(100) \\
69 \\
(81.2)\end{array}$ & $\begin{array}{l}16 \\
(19.3) \\
0 \\
16 \\
(18.8)\end{array}$ & $\begin{array}{l}83 \\
2 \\
85 \\
(100)\end{array}$ & $\begin{array}{c}\text { 0.04, slight } \\
\quad(0.49)\end{array}$ \\
\hline $\begin{array}{c}\text { CPIS, } \mathrm{n}(\%) \\
\text { Positive } \\
\text { Negative } \\
\text { Total }\end{array}$ & $\begin{array}{l}11 \\
(17.5) \\
17 \\
(77.3) \\
28 \\
(32.9)\end{array}$ & $\begin{array}{l}8 \\
(12.7) \\
1(4.5) \\
9 \\
(10.6)\end{array}$ & $\begin{array}{l}44 \\
(69.8) \\
4 \\
(18.2) \\
48 \\
(56.5)\end{array}$ & $\begin{array}{l}63 \\
22 \\
85 \\
(100)\end{array}$ & $\begin{array}{c}0.42, \text { moderate } \\
(<0.001)\end{array}$ & $\begin{array}{l}61 \\
(96.8) \\
8(36.4) \\
69 \\
(81.2)\end{array}$ & $\begin{array}{l}2(3.2) \\
14 \\
(63.6) \\
16 \\
(18.8)\end{array}$ & $\begin{array}{l}63 \\
22 \\
85 \\
(100)\end{array}$ & $\begin{array}{l}\text { 0.663, substantial } \\
\qquad<0.001)\end{array}$ \\
\hline
\end{tabular}

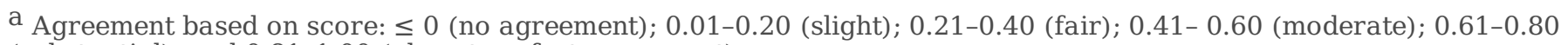
(substantial); and 0.81-1.00 (almost perfect agreement).

CDC/NHSN: centers for disease control and prevention national health safety network; CPIS: Clinical Pulmonary Infection Score, HELICS: Hospital in Europe Link for Infection Control through Surveillance

Table 6. Kappa agreement coefficient among ventilator-associated pneumonia diagnostic methods.

\begin{tabular}{|l|l|l|}
\hline Criteria & Kappa () index, agreement level & p-Value \\
\hline CPIS and Johanson & 0.874 & $<0.001$ \\
\hline CDC/NHSN and Johanson & 0.145 & $<0.001$ \\
\hline CDC/NHSN and CPIS & 0.129 & 0.015 \\
\hline
\end{tabular}

a Agreement based on score: $\leq 0$ (no agreement); 0.01-0.20 (slight); 0.21-0.40 (fair); 0.41- 0.60 (moderate); 0.61-0.80 (substantial); and 0.81-1.00 (almost perfect agreement).

CDC/NHSN: centers for disease control and prevention national health safety network; CPIS: Clinical Pulmonary Infection Score, HELICS: Hospital in Europe Link for Infection Control through Surveillance

Table 7. Correlation of individual variables with ventilator-associated pneumonia diagnostic methods.

\begin{tabular}{|l|l|l|l|}
\hline \multirow{2}{*}{ Parameter } & \multicolumn{3}{|c|}{ Kappa agreement coefficient } \\
\cline { 2 - 4 } & CDC/NHSN & CPIS & Johanson \\
\hline PCT $>0.5 \mathrm{ng} / \mathrm{ml}$ & 0.061 & 0.423 & 0.470 \\
\hline Infiltrate on radiograph & -0.045 & 0.874 & 0.738 \\
\hline Temperature & -0.044 & 0.529 & 0.579 \\
\hline $\mathrm{WBC}$ & -0.044 & 0.739 & 0.729 \\
\hline $\mathrm{P}_{\mathrm{a}} \mathrm{O}_{2}$ & -0.038 & 0.094 & -0.139 \\
\hline Tracheal culture & 0.044 & 0.663 & 0.579 \\
\hline Blood culture & -0.011 & 0.238 & 0.165 \\
\hline
\end{tabular}

CDC/NHSN: centers for disease control and prevention national health safety network; CPIS: Clinical Pulmonary Infection Score, HELICS: Hospital in Europe Link for Infection Control through Surveillance, PCT: Serum procalcitonin; WBC: White 


\section{Figures}

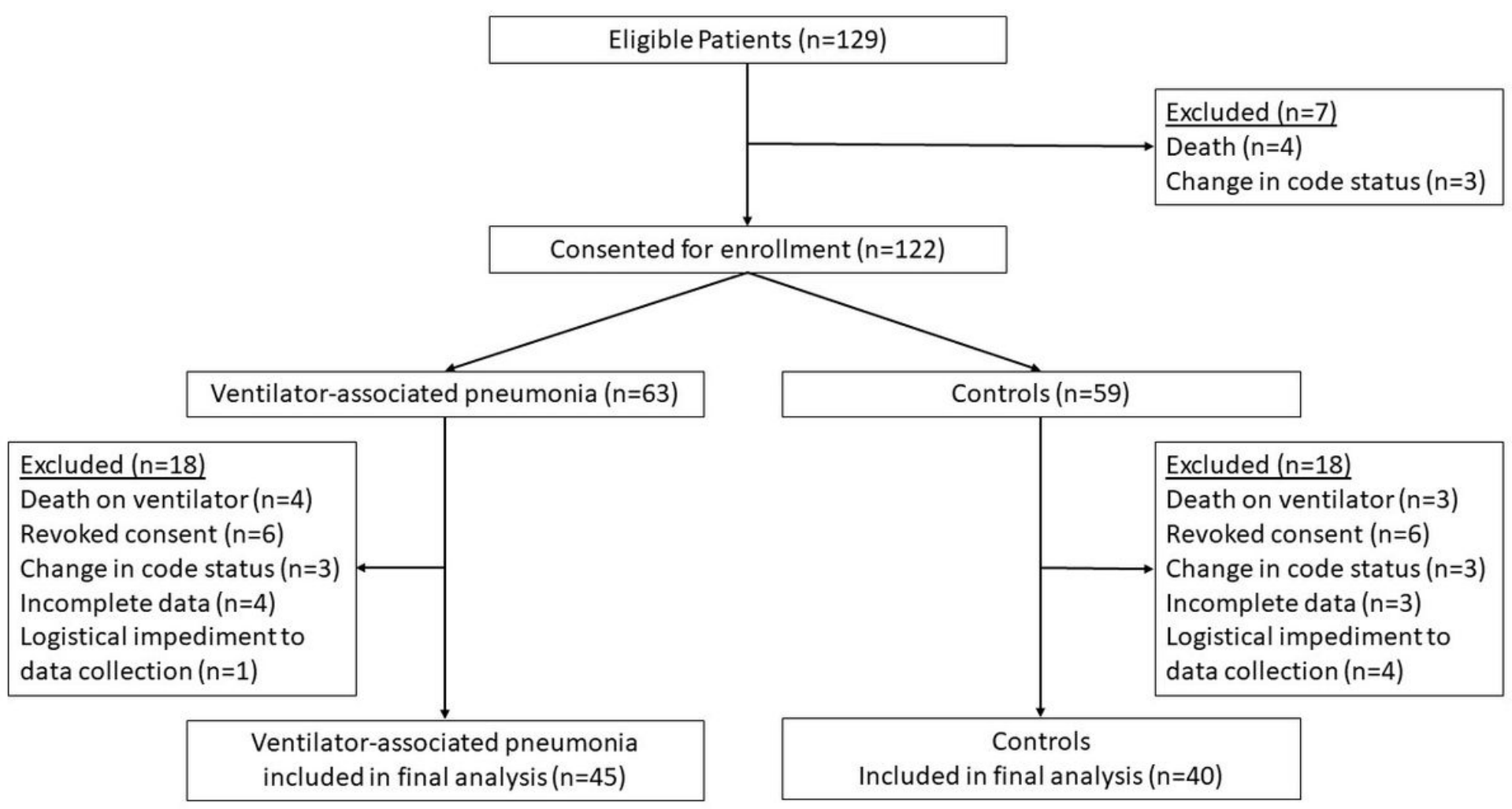

Figure 1

Patient flow diagram. 